\title{
Unveiling the Nanotechnology-Based Drug Delivery Systems and Patent Literature for Diabetic Retinopathy
}

\author{
Sukhbir Singh 1 (D), Yuvraj Batish 1, Neelam Sharma 1,* (D), Sandeep Arora 1 (D), Vansh Kakkar ${ }^{1}$, \\ Sudhanshu Batra ${ }^{1}$ \\ 1 Chitkara College of Pharmacy, Chitkara University, Punjab, India \\ * Correspondence: neelam.mdu@gmail.com (N.S.);
}

Scopus Author ID: 57214054056

Received: 22.05.2021; Revised: 16.09.2021; Accepted: 20.09.2021; Published: 19.11.2021

\begin{abstract}
Diabetes mellitus is a principal reason for globally developing chronic microvascular disorders defined as diabetic retinopathy (DR). Proliferative retinopathy and non-proliferative retinopathy are the two types of DR. Long-term diabetes, and poor blood sugar and arterial blood pressure regulation are the key risk factors for the onset and advancement of DR. A variety of biochemical pathways are involved in the pathogenesis of DR, which includes increased polyol pathway fluxes, advanced glycation end product growth, protein kinase $\mathrm{C}$ isoform activation, and increased hexosamine pathway flux. The varieties of cells are involved in diabetic retinopathy, including glial cells, retinal ganglion cells, endothelial cells, and pericytes. Surgical treatment of DR includes laser treatment, panretinal photocoagulation, focal laser photocoagulation, and vitrectomy surgery. The systemic treatment of DR includes glycemic management and control of blood pressure and hyperlipidemia. Nanotechnology-based formulations like nanoparticles, polymeric nanomicelles, and nanocarrier composite, and various patented formulations have been investigated for the treatment of DR.
\end{abstract}

Keywords: diabetes mellitus; diabetic retinopathy; laser treatment; panretinal photocoagulation; vitrectomy surgery; nanotechnology.

(C) 2021 by the authors. This article is an open-access article distributed under the terms and conditions of the Creative Commons Attribution (CC BY) license (https://creativecommons.org/licenses/by/4.0/).

\section{Introduction}

Diabetes mellitus (DM) is a leading cause of diabetic retinopathy (DR) and promptly developing chronic diseases worldwide. DR is the microvascular complication of diabetes, continues to be the leading cause of acquired vision loss in middle-aged and, therefore, economically involved people around the world [1]. With the prevalence of diabetes, the number of people with DR and vision-threatening DR (VTDR), which involves extreme nonproliferative DR (NPDR) and proliferative DR (PDR), is expected to increase to 191 million and 56.3 million by 2030. The enhanced vascular permeation and capillary blockage are imperative causes that lead to alteration in the vasculature of the retina in NPDR, which characterize the initial phase of DR. Fundus photography may perhaps diagnose retinal disorders like micro-aneurysms, hemorrhages, and hard exudates. PDR is a progressive stage and is distinguished by neovascularization. Patients can experience severe vision loss if the dysfunctional vessels bleed into the vitreous or if the tractional retinal detachment is there. Diabetic macular edema (DME) is the most frequent cause of vision loss in DR patients. DME is marked by swelling or thickening of the macula as a result of sub- and intra-retinal fluid 
deposition in the macula attributable to a weakening of the blood-retinal barrier. DME may happen at whichever DR stage, resulting in visual deformations and loss of sight acuity [2-5].

\section{Risk Considerations for Diabetic Retinopathy}

The risk parameters for DR can be widely categorized into two types (Figures 1 and 2). Hyperglycemia, hypertension, hyperlipidemia, and obesity are modifiable risk factors. Nonmodifiable risk factors for DR growth and development include diabetes duration, puberty, and pregnancy [6-11].

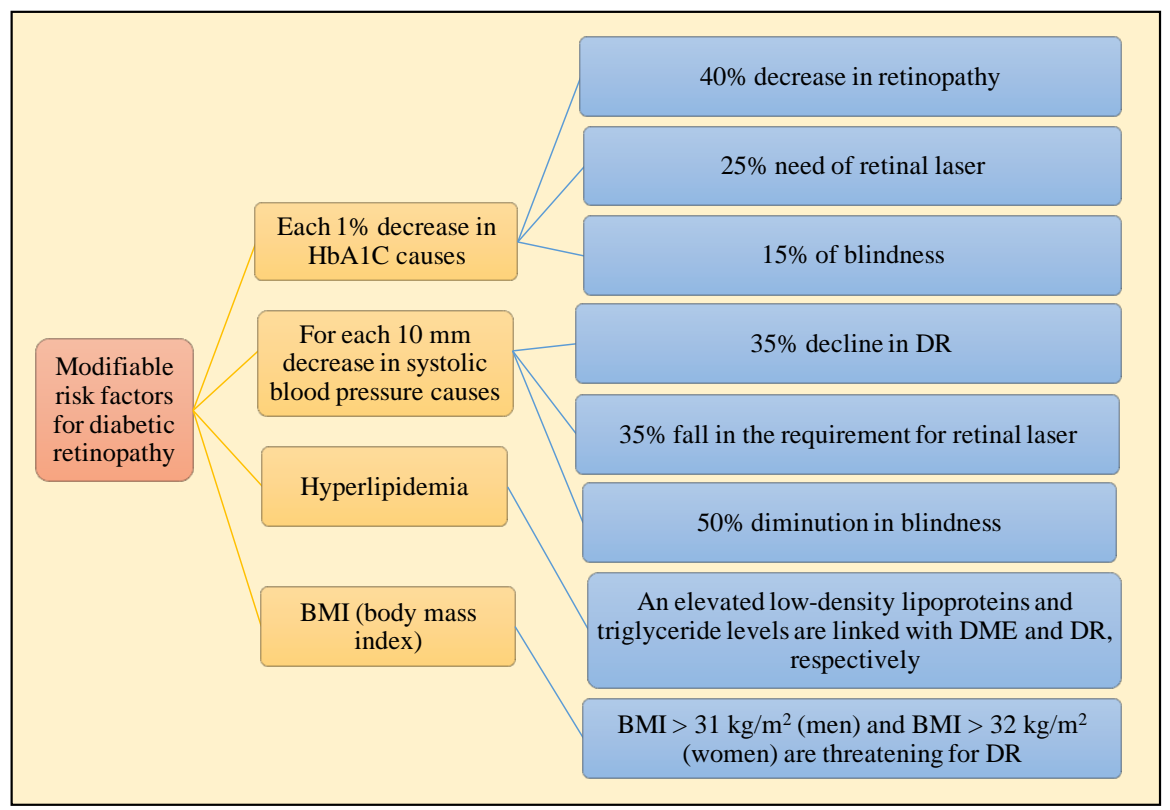

Figure 1. Modifiable risk factors and interventions in diabetic retinopathy.

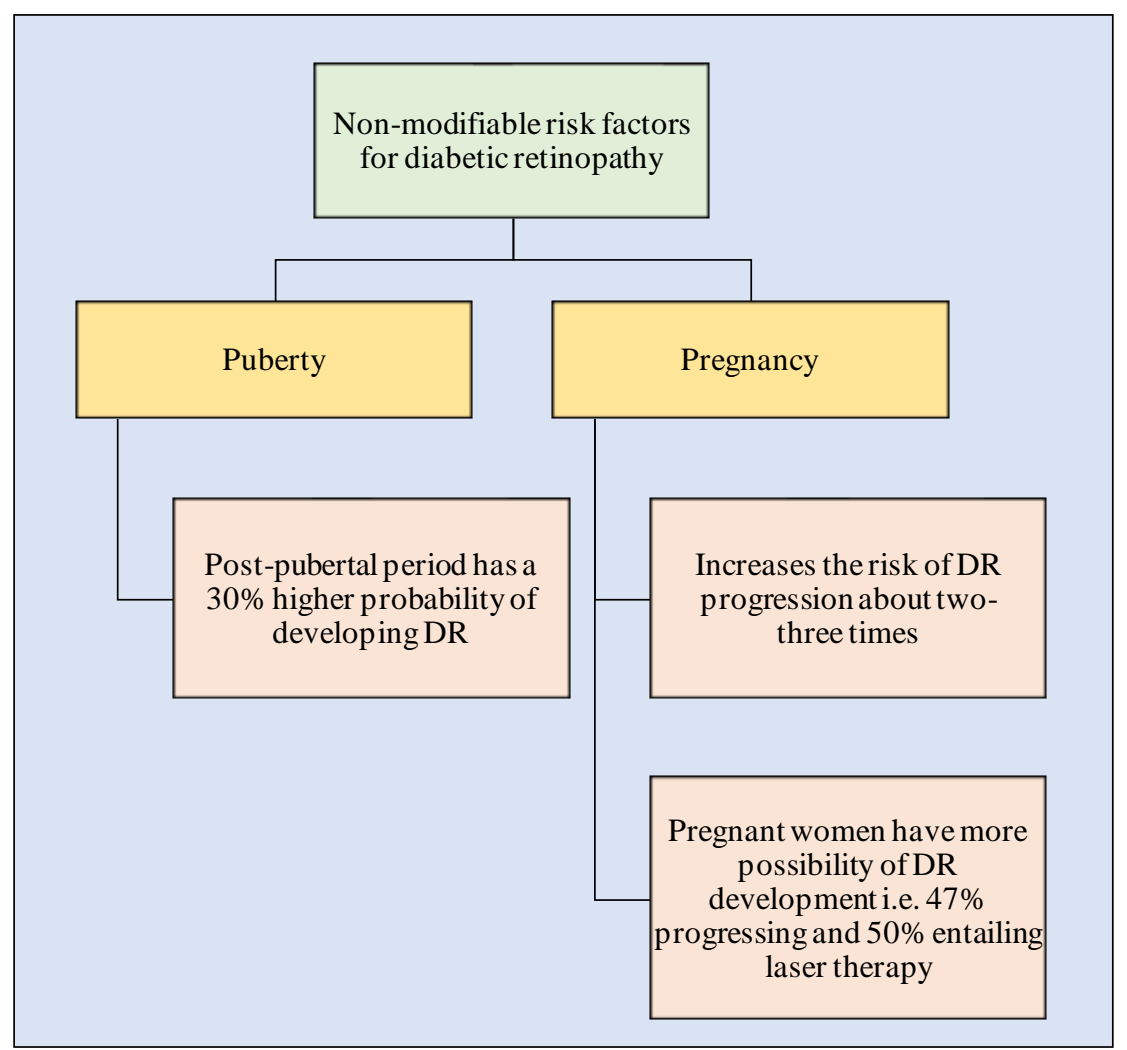

Figure 2. Non-modifiable risk parameters and interference in diabetic retinopathy. 


\section{Clinical Pathophysiology of Diabetic Retinopathy}

BRB malfunctioning generally occurs in diabetic retinopathy (DR). The seepage of blood components within the neuropile of the retina happens concurrently in consequence of weakening of an internal BRB, which recurrently results in diabetic macular edema. VEGF has been linked to blood vessel leakage and serves as a persuasive vascular permeability factor [12]. The increased expression of collagen, fibronectin, and laminin contributes to improvements in the microenvironmental conditions mediating development and longevity, including the role of pericytes and endothelial cells, which is thought to cause thickening of the vascular basement membrane in DR [13]. The lack of pericyte function is core to the pathophysiology of degenerative capillaries seen in DR. Pericytes are essential for normal retinal function because they help angiogenic endothelial cells differentiate, migrate, and proliferate [14]. Pericyte deficiency and the appearance of "pericyte ghosts" are thus considered important histopathological features of DR [15].

\section{Molecular Mechanisms for Diabetes Associated Retinopathy}

The most common reason for microvascular problems is hyperglycemia. The induction of chronic, low-grade inflammatory signaling and metabolic instability caused by high glucose play a key role in the development of DR. Hemorrhages, microaneurysms, cotton-wool spots, lipid exudates, macular edema, capillary occlusion, and eventually neovascularization are all clinical symptoms of retinopathy [16]. The pathogenesis of DR involves a number of biochemical pathways like polyol flux, advanced glycation end (AGE) product development, oxidative stress, and activation of protein kinase $\mathrm{C}$ (PKC). Figure 3 represents sequential pathophysiology leading to retinal neovascularization and eventually vision loss [17-25].

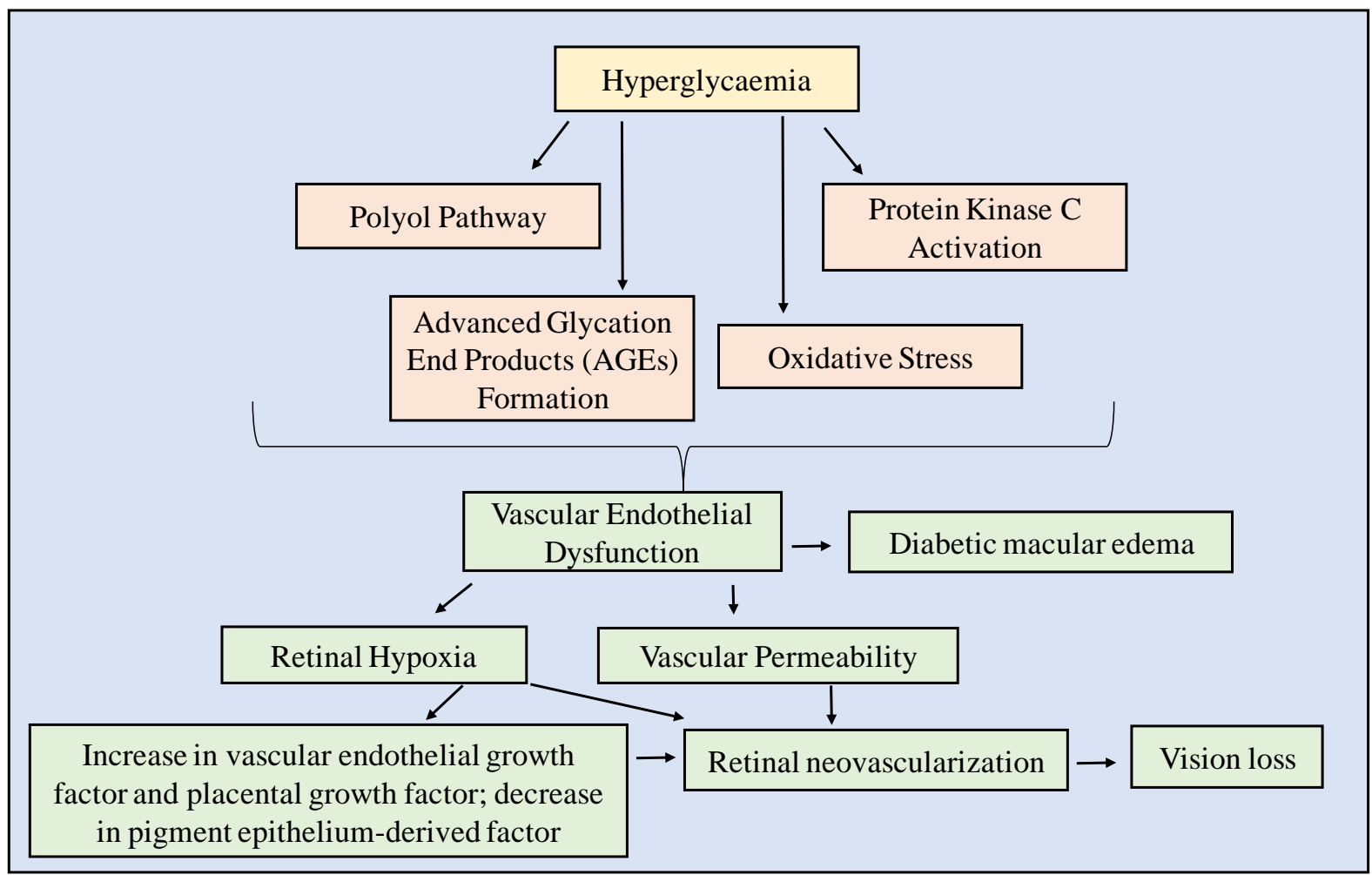

Figure 3. Graphical representation of pathophysiology leading to the development of diabetic retinopathy. 


\subsection{Advanced glycation end product (AGEs) formation.}

The provocative occurrence for the formation of AGEs is intracellular hyperglycemia, which is present in higher concentrations in diabetic retinal blood vessels [26] and glomeruli [27]. They are formed when intracellular glucose is auto-oxidized to glyoxal and further decomposed and fragmented to methylglyoxal, which reacts with amino residues of intra- and extracellular proteins to produce AGEs [28,29].

\subsection{Polyol pathway.}

Hyperglycemia causes an increase in the conversion of glucose to sorbitol, as well as a reduction in NADPH (nicotinamide adenine dinucleotide phosphate). Sorbitol oxygenation is thought to boost the ratio of NADH and NAD+ within the cytosol, which causes inhibition of glyceraldehyde-3-aldehyde dehydrogenase (GAPDH) activity. This results in higher levels of triose phosphate, which promotes the production of methylglyoxal, AGE precursor, and diacylglycerol, therefore triggering PKC [30]. Moreover, as NADPH is needed for the regeneration of reduced glutathione, therefore, reducing glucose to sorbitol absorbs NADPH which causes potential exacerbation of oxidative stress.

\subsection{Oxidative stress.}

The hyperglycemia causes an increase in reactive oxygen species (ROS) activities which lead to activation of poly-(ADP-ribose) polymerase (PARP) enzyme. This causes a decrease in GAPDH activity which accelerates methylglyoxal formation and AGEs production [31,32].

\subsection{Protein kinase C (PKC) activation.}

Excess glucose flux through the glycolysis pathway is also a result of hyperglycemia. The PKC pathway is activated due to this increase in diacylglycerol synthesis [33-35]. High expression of PKC in DR causes overexpression of NADPH oxidase in vascular endothelial cells, which aggravate oxidative stresses and ROS activities [36].

\section{Cells Involved in Diabetic Retinopathy}

The cells which are implicated in the diabetic retinopathy process are shown in Figure 4. Glial cells, retinal ganglion cells (RGCs), and other neuronal cells make up the neural unit [37]. Energy balance and synaptic transfer modulation are made possible by their close relationship. They also play a role in producing BRBs, which have high selectivity as a controlling barrier [38].

\subsection{Role of glial cells and retinal ganglion cells in diabetic retinopathy.}

Glial cells comprise astrocytes, microglia, and muller cells, which play a potential role in preserving retinal homeostasis. They play a role in phagocytosis of neuronal fragments, metabolism and in releasing numerous transmitters, dietary factors, potassium ion uptake, and imparts structural integrity [39]. RGCs are the only efferent neuron that can transfer sensory input to the brain via retina since their cell bodies are situated in the ganglion cell layer and their dendrites are located in multiple inner plexiform layers to interact with different presynaptic neurons [40-43]. 


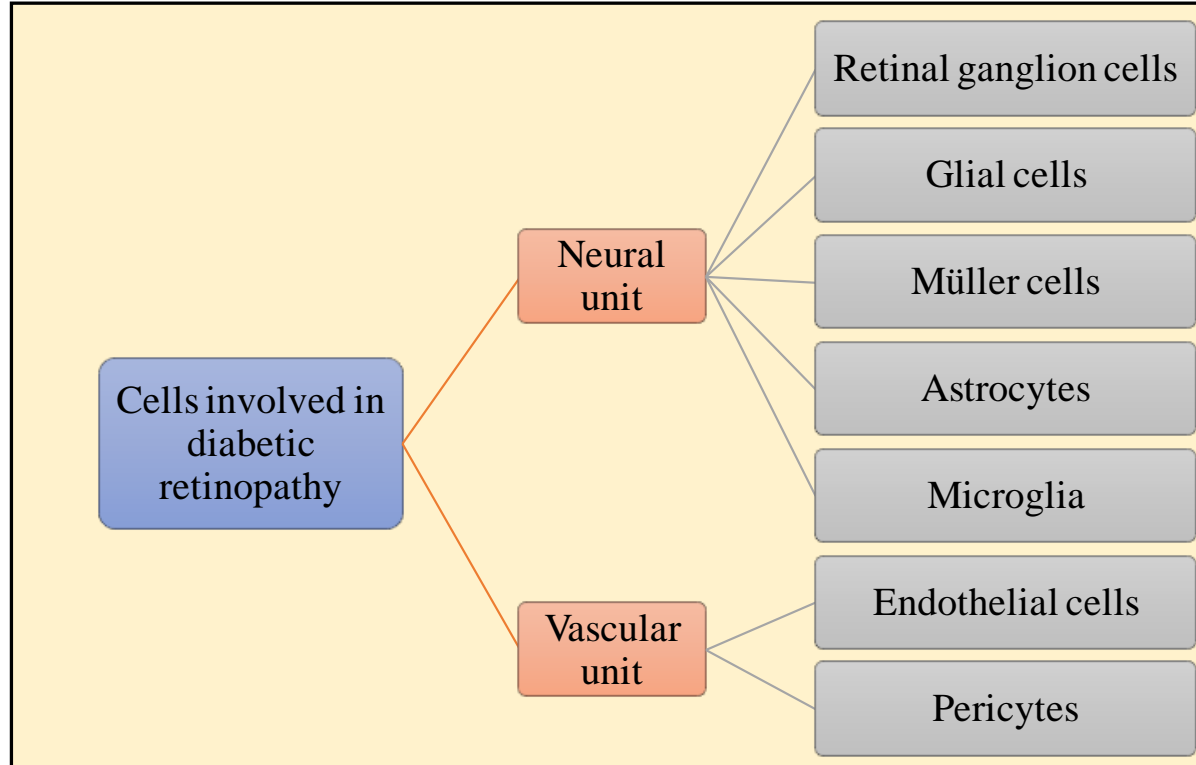

Figure 4. Types of cells involved in diabetic retinopathy.

RGC deficiency is a common pathological characteristic in diabetic retinal neurodegeneration [44], and may contribute to early neurovascular unit disturbance $[45,46]$. One of the main mechanisms of RGC deficiency is the aggregation of ROSs and oxidative stress that can be exacerbated by the diabetic environment [47-50].

\subsection{Astrocytes for upholding blood-retinal-barrier integrity.}

Astrocytes comprise the innermost coating of the retina and play a fundamental function in maintaining BRB integrity. The majorly of these cells are found in vascular regions of the retina, while avascular zones have fewer astrocytes. Astrocytes appear to play a role in neuronal signal transduction, ion homeostasis and are an important component of BRB. Stimulated astrocytes lead to proliferation leading to hypertrophic conditions and taking on a stellate morphology. Astrocytes, T-cells, microglia, and monocytes/macrophages are stimulated and develop several pro-inflammatory cytokines and chemokines in the diabetic environment, which is marked by dysmetabolic and hypoxic conditions augmenting the inflammatory response [51]. Astrocytes are among key producers of vascular endothelial growth factors (VEGF). Reactive gliosis increases the expression of the glial fibrillary acidic protein (GFAP) inside astrocytes. After that, the lack of astrocytes causes inner BRB deficiency and retinal vascular leakage [52].

\subsection{Involvement of microglia and Muller cells in diabetic retinopathy.}

Microglia, the retina's resident inflammatory cells, plays a role in neural network production and maintenance in addition to immunologic action. Microglia cells are present practically in each layer of a normal retina. The subdivisions of microglia remained aligned along optic nerve fibers, but this kind of alignment gets disordered in DM [53]. During the activated state, the distribution and composition of microglia change in a variety of pathological conditions. Microglia cells use phagocytic and cytotoxic pathways, similar to macrophages, to degrade foreign materials. Based on the intensity and type of tissue dysfunction or inflammation, these cells transform from resting to active [54]. Enhanced perivascular microglia cells settle inside the plexiform of the retina-microglia cells gathered in large numbers in ischemic areas and newly dilated blood vessels in PDR. Microglia and 
RGC interaction can also be observed in epiretinal membranes [55]. The retina is inflamed for a long time as a result of DR. The chronic inflammation raises expression of interleukin-6 (IL6) in ocular fluids of DR patients, which leads to interaction among microglia and retinal pigment epithelium (RPE), causing outer BRB disturbance [56,57]. IL-6 increases the VEGF expression in RPE, which causes mobilization of microglia to RPE ensuing larger secretion of tumor necrosis factor (TNF)- $\alpha$, which contributes directly to oBRB disruption $[58,59]$.

Muller cells cover the whole retina from the interior side, restraining membrane from the outside makes it a perfect supervisor for controlling pathological and physiological responses of retinal neurons as well as vasculature $[39,60]$. Muller cells can serve their role in retinal metabolism, functions, repair, and defense via removing metabolic wastes, supplying nutrition, and releasing neurotransmitters engaged in vision cycles, controlling BRB activity, and modulating innate immunity [61]. Muller cells serve as the center of the neurovascular complex, where nutrients and oxygen are exchanged. Furthermore, Muller cells provide the eye with the majority of its dietary support [62]. Retinoschisis is caused by the selective removal of Muller cells from the retina, implying that these can provide elasticity to the retina $[63,64]$. During DR, the interaction occurs between Muller cells as well as vascular unit is disrupted, and they develop significant quantities of factors, some of which have a protective effect, while others, such as VEGF, exacerbate the problem [65]. The up-regulation of VEGF occurs during preliminary phases of DR and exerts neuroprotective outcomes. Muller cells secrete VEGF, which improves the blood supply and contributes to BRB collapse during DM [66]. These cells develop dynamic, specific, and reactive phenotypes in DR, which generates a persistent inflammatory environment [67]. Hypoxia-inducible factor-1 rises in vitreous, which stimulates Muller cells, ultimately creating the chronic inflammatory environment and leading to accumulation and overexpression of fibroblast growth factor, ultimately leading to retinal fibrosis and pathological neovascularization [68].

\subsection{Pericytes and endothelial cells: the fundamental vascular units.}

Pericytes are blood microvessels that exhibit an important role in angiogenesis, blood flow regulation, and BRB integrity [69,70]. Pericytes insert themselves in the endothelial basal layer, develop structured bonding with ECs, and contribute to platelet-derived growth factor receptor signal transduction [71]. Hyperglycemia causes depletion of this signaling system, resulting in pericytes apoptosis, resulting in a lack of structural support for retinal capillaries and leading to a localized failure of the vascular membrane [72].

Amongst the most significant components of inner BRB are close dynamic connections of endothelial cells (ECs). The endothelial form in the retina differs greatly depending on the type of vessel. ECs are a complex, semi-selective barrier that regulates fluid and macromolecule transfer between the blood and the interstitium and regulates inflammatory reaction and angiogenesis [73]. Over-expression of many cytokines, including TNF- $\alpha$, VEGF, IL-6, with vascular cellular adhesion molecule-1 is linked to retinal microvascular dysfunction [74]. In high-glucose conditions, the expression of Toll-like receptors, which play an important role in modulating inflammatory responses, is dramatically increased in retinal ECs [75]. Retinal ischemia is caused by increased capillary occlusion, and hypoxia in DR induces an increase in VEGF levels, which facilitates pathological neovascularization. VEGF activates the receptors on ECs, promoting EC durability, multiplication, and porosity against VEGF sources, which are necessary steps in producing and maintaining blood vessels [76-80]. 


\section{Treatment Strategies for Diabetic Retinopathy}

The classification of various treatment strategies for DR includes numerous surgical procedures, systemic therapies, and nanotechnology-based strategies, as described in Figure 5.

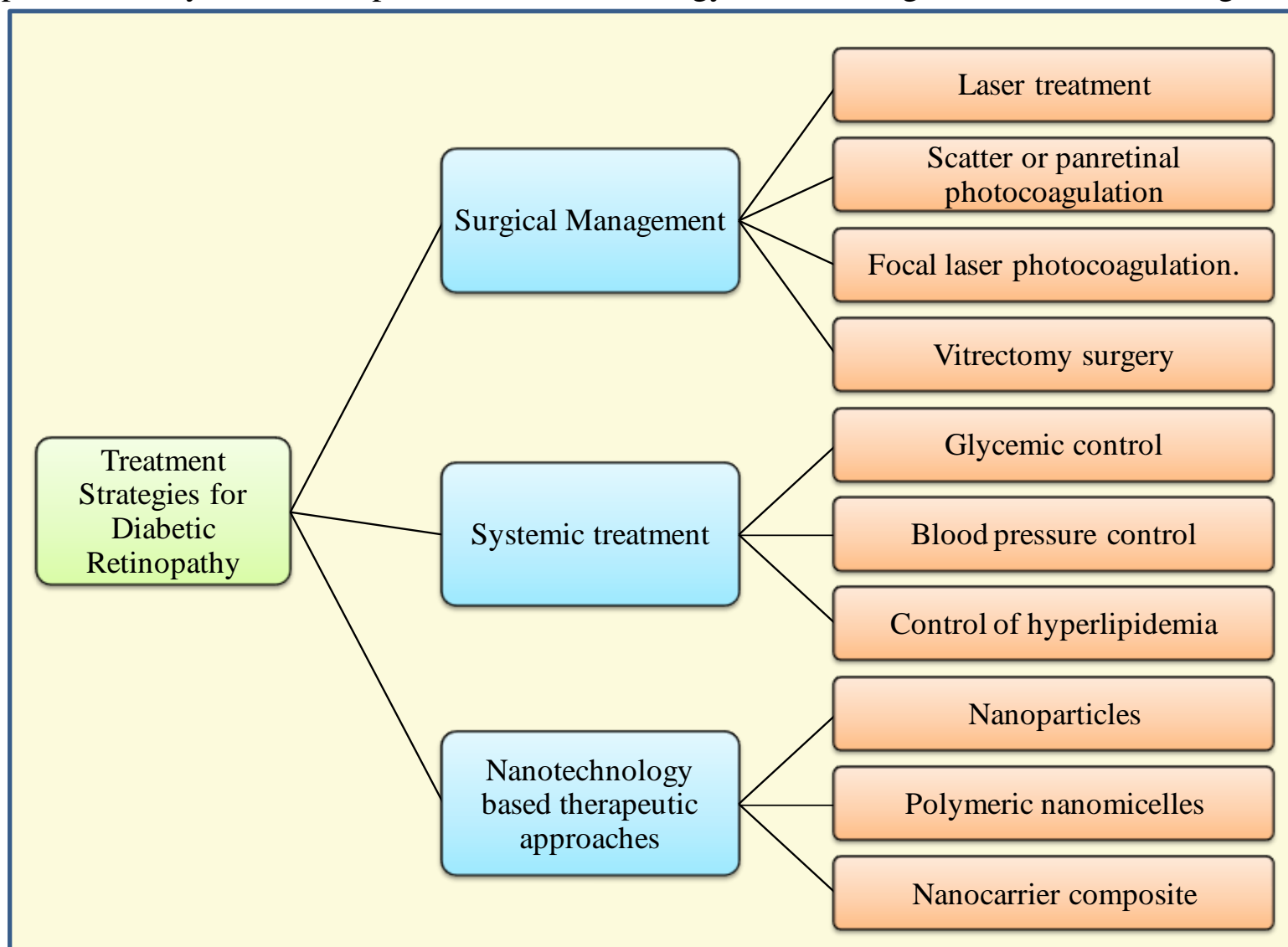

Figure 5. The categorization of various treatment approaches for diabetic retinopathy.

\subsection{Surgical management.}

\subsubsection{Vitrectomy surgery.}

Vitrectomy is a surgical procedure that removes the vitreous gel from the eye. A translucent jelly-like fluid called vitreous holds about two-thirds of the eye between the lens and the retina. Vitrectomy stops more vitreous hemorrhage by destroying the dysfunctional blood vessels that cause bleeding as well as the scar tissue and avoiding progressive vision loss [81-83]. The success rate of vitrectomy surgery is very high. Any surgical operation carries the risk of complications such as vitreous hemorrhage, cancer, retinal tears, cataract progression, and retinal detachment $[84,85]$.

\subsubsection{Laser photocoagulation and panretinal photocoagulation (PRP).}

Laser photocoagulation has been shown to be a successful therapy for maintaining eyesight as well as decreasing the likelihood of vision loss from DR over the last few decades [86]. The primary goal of laser photocoagulation in the retina should be the reversal of dysfunctional capillaries and angiogenesis. An argon laser can be used with two different laser techniques. PRP is a kind of laser therapy that is utilized to treat anomalous blood capillaries in either retina or drainage configuration inside the eyeball. It entails tissue oxygenation and overturns hypoxia [87]. 


\subsubsection{Focal laser photocoagulation.}

Individually bleeding blood vessels in the eye are targeted with focal laser therapy. The retina was treated with slighter intense and less laser energy spots in this method [86]. The laser therapy takes between 15-20 minutes. Laser therapy is not approved for slight to severe nonproliferative DR. While laser therapy will not be sufficient to replace lost visual, it is meant to avoid further vision loss. While laser therapy has been shown to improve or stabilize visual perception if used properly, effectively, and well-timed, however, this method has several adverse consequences like moderate vision failure and diminished night and color visualization [88], decreased contrast sensitivity [89], and decreased ability to concentrate [90].

\subsection{Systemic treatment.}

Few experimental therapies for DR have shown promising outcomes in animals and/or human patients. Any biochemical mechanisms linked to hyperglycemia and DR are inhibited by the medications. A variety of targets must be met in order to lower a sufferer's chance of developing retinopathy. Topical, systemic, and local administration of eye medications is some options (intravitreal, subretinal, subconjunctival, sub-tendon, peribulbar, and retrobulbar routes). The growth and progression of DR may be slowed by controlling systemic glucose [91-93], blood pressure [94-98], and lipid levels [99-102]. However, these medicines used for such treatments have severe side effects.

\subsection{Nanotechnology-based therapeutic approaches.}

Nanotechnology performs together at atomic and molecular levels and has been proficient in science and technology for therapeutics, diagnosis [103,104], and biomedical application $[105,106$.$] . Nowadays, this has been gaining enormous significance in the field of$ pharmaceuticals in various routes like oral, ocular, inhalable, parenteral, rectal, and topical [107] and types of drug delivery systems like immediate, sustained, and controlled drug delivery [108]. It has the prospective to unlock innovative strategies for the treatment of diabetic retinopathy [109-112]. Nanomedicines incorporate nanoparticles to achieve superior drug targeting, diminished toxicity, and improved efficiency of therapeutic or diagnostic agents. Polymeric nanoparticles are sub-micron carriers having approximately 1-100 nm scale comprised of biodegradable and biocompatible polymers and are considered strategic tools for specific drug delivery at the site of action and advanced bioavailability [110-113]. Polymeric nanomicelles are produced self-assembling amphiphilic polymers and designate as a pioneering tool to conquer numerous problems associated with drug delivery from poorly permeable drugs across biological barriers, such as in ocular drug delivery for diabetic patients retinopathy management [114,115]. Polymeric biodegradable nanocomposites are heterogeneous materials that are synthesized using the blends of biocompatible and biodegradable polymers at a nanometric scale [116,117]. The application of nanotechnology approaches like nanoparticles, polymeric nanomicelles, and polymeric nanocarrier composite in drug therapeutics have been investigated by several researchers and have discovered their superior efficacy with an outcome of improved treatment of DR as summarized in Table 1. 
Table 1. Nano-based formulations investigated for the treatment of diabetic retinopathy.

\begin{tabular}{|c|c|c|c|}
\hline Research and outcome & Drug & Method & Ref. \\
\hline $\begin{array}{l}\text { Fenofibrate-loaded biodegradable nanoparticles } \\
\text { for treatment of DR and neovascular age-related } \\
\text { macular degeneration }\end{array}$ & $\begin{array}{l}\text { Fenofibrate, poly(lactic-co-glycolic } \\
\text { acid), Tween } 80 \text {, dichloromethane }\end{array}$ & Emulsification & [111] \\
\hline $\begin{array}{l}\text { A non-invasive nanoparticle-mediated delivery } \\
\text { of triamcinolone acetonide ameliorates could be } \\
\text { used as a topical formulation for treating DR }\end{array}$ & $\begin{array}{l}\text { Triamcinolone acetonide, } \\
\text { Polycaprolactone, pluronic } ® \text { F- } 68, \\
\text { Poly (d, l-lactide-co-glycolide) }\end{array}$ & Nanoprecipitation & [112] \\
\hline $\begin{array}{l}\text { Celecoxib-loaded nanoparticles topical } \\
\text { ophthalmic formulations used for anterior eye } \\
\text { disorders and also for the treatment of diseases } \\
\text { associated with the posterior eye }\end{array}$ & $\begin{array}{l}\text { Celecoxib, chitosan, sodium alginate, } \\
\text { poly- } \varepsilon \text {-caprolactone (PCL), poly-L- } \\
\text { lactide, and poly-D,L-lactide-co- } \\
\text { glycolide }\end{array}$ & $\begin{array}{l}\text { Emulsification } \\
\text { solvent diffusion }\end{array}$ & [113] \\
\hline $\begin{array}{l}\alpha \text {-Lipoic acid in soluplus }{ }^{\circledR} \text { polymeric } \\
\text { nanomicelles for the ocular treatment of } \\
\text { diabetes-associated corneal diseases }\end{array}$ & $\begin{array}{l}\alpha \text {-Lipoic acid (ALA), sodium } \\
\text { dioctylsulfosuccinate, Soluplus }\end{array}$ & Freeze drying & [115] \\
\hline $\begin{array}{l}\text { Chitosan-sodium alginate-fatty acid nanocarrier } \\
\text { composite for treatment of DR }\end{array}$ & Lutein, chitosan, oleic acid & $\begin{array}{l}\text { Ionotropic } \\
\text { gelation }\end{array}$ & [117] \\
\hline $\begin{array}{l}\text { Formulation of PPAR-gamma agonist as } \\
\text { surface-modified polylactic acid-co-glycolic } \\
\text { acid (PLGA) nanoparticles and concluded that } \\
\text { pioglitazone loaded surface-modified PLGA } \\
\text { nanoparticles have great potential to treat DR }\end{array}$ & $\begin{array}{l}\text { Pioglitazone, dichloromethane, } \\
\text { polysorbate } 80 \text {, Polyvinyl alcohol and } \\
\text { mannitol }\end{array}$ & $\begin{array}{l}\text { Single emulsion } \\
\text { solvent } \\
\text { evaporation }\end{array}$ & [118] \\
\hline $\begin{array}{l}\text { Enhancement of scutellarin oral delivery } \\
\text { efficacy by vitamin B12-modified amphiphilic } \\
\text { chitosan derivatives for treatment type II } \\
\text { diabetes induced-retinopathy }\end{array}$ & $\begin{array}{l}\text { Scutellarin, Chitosan, Deoxycholic } \\
\text { acid, Vitamin B12 }\end{array}$ & $\begin{array}{l}\text { Self-assembly in } \\
\text { aqueous medium }\end{array}$ & [119] \\
\hline $\begin{array}{l}\text { Intravitreal injection of bevacizumab-chitosan } \\
\text { nanoparticles inhibited angiogenesis of DR. } \\
\text { Research indicated that the intravitreal injection } \\
\text { of bevacizumab inhibited the VEGF-expression } \\
\text { in the retina, and bevacizumab-chitosan } \\
\text { nanoparticles have a longer duration of action }\end{array}$ & Bevacizumab, chitosan & $\begin{array}{l}\text { Emulsification } \\
\text { evaporation }\end{array}$ & {$[120]$} \\
\hline
\end{tabular}

\section{Patents Reported for Treatment and Diagnosis of Diabetic Retinopathy}

The recent patents based on various herbal and synthetic formulations for treatment or diagnosis of DR and associated problems have been searched from the PATENTSCOPE database and summarized in Table 2. This patent literature indicates that continuous efforts are under process for exploring several additional therapeutic measures for DR.

Table 2. Patented formulations for diabetic retinopathy.

\begin{tabular}{|c|c|c|c|c|}
\hline Patent title & Patent number & Applicant & $\begin{array}{l}\text { Publication } \\
\text { date }\end{array}$ & Ref. \\
\hline $\begin{array}{l}\text { The herbal formulation for prevention and } \\
\text { treatment of diabetic retinopathy }\end{array}$ & IN1223/DEL/2009 & $\begin{array}{l}\text { Innoveda Biological } \\
\text { Solutions Pvt. Ltd }\end{array}$ & 24.12 .2010 & [121] \\
\hline $\begin{array}{l}\text { Pharmaceutical composition and formulation } \\
\text { for non-invasive eye treatment and uses } \\
\text { thereof }\end{array}$ & WO2016205908 & University of Campinas & 29.12 .2016 & [122] \\
\hline $\begin{array}{l}\text { Marker for diagnosing diabetic retinopathy } \\
\text { and use thereof }\end{array}$ & WO2014003343 & $\begin{array}{l}\text { LG Electronics Inc. } \\
\text { SNU R\&DB Foundation }\end{array}$ & 03.04 .2014 & [123] \\
\hline $\begin{array}{l}\text { Traditional Chinese medicine formulation for } \\
\text { treating diabetic retinopathy }\end{array}$ & CN106309841 & Wang Yongchao & 01.01 .2017 & [124] \\
\hline $\begin{array}{l}\text { A novel formulation of } 5 \text {-fluorouracil for } \\
\text { treating diabetic retinopathy }\end{array}$ & IN201911049029 & $\begin{array}{l}\text { Lovely Professional } \\
\text { University }\end{array}$ & 20.12 .2019 & [125] \\
\hline Topical ophthalmic peptide formulation & NZ600627 & BCN Peptides S.A. & 29.08 .2014 & [126] \\
\hline $\begin{array}{l}\text { Advancement inhibitor or therapeutic agent } \\
\text { for diabetic retinopathy simplex }\end{array}$ & JP1995242547 & $\begin{array}{l}\text { Sanwa Kagaku } \\
\text { Kenkyusho Co Ltd }\end{array}$ & 19.09 .1995 & [127] \\
\hline $\begin{array}{l}\text { Formulations comprising a compound that } \\
\text { activates tie- } 2 \text { and their use in treating ocular } \\
\text { diseases }\end{array}$ & GB2540638 & Aerpio Therapeutics Inc & 25.01 .2017 & [128] \\
\hline
\end{tabular}




\begin{tabular}{l|l|l|l|l}
\hline Patent title & Patent number & Applicant & $\begin{array}{l}\text { Publication } \\
\text { date }\end{array}$ & Ref. \\
\hline $\begin{array}{l}\text { Methods and devices for drug delivery to } \\
\text { ocular tissue using microneedle }\end{array}$ & NZ623752 & $\begin{array}{l}\text { Georgia Tech Research } \\
\text { Corporation } \\
\text { Emory University }\end{array}$ & 31.07 .2015 & {$[129]$} \\
\hline $\begin{array}{l}\text { Subconjunctival depot forming formulations } \\
\text { for ocular drug delivery }\end{array}$ & WO2017184081 & $\begin{array}{l}\text { Nanyang Technological } \\
\text { University }\end{array}$ & 26.10 .2017 & {$[130]$} \\
\hline $\begin{array}{l}\text { Micro-RNA-195 compositions and } \\
\text { therapeutic use in ocular diseases }\end{array}$ & WO2018111784 & $\begin{array}{l}\text { China Medical } \\
\text { University }\end{array}$ & 21.06 .2018 & {$[131]$} \\
\hline $\begin{array}{l}\text { The herbal formulation for prevention and } \\
\text { treatment of diabetes and associated } \\
\text { complications }\end{array}$ & US20110236488 & $\begin{array}{l}\text { Innoveda Biological } \\
\text { Solutions Pvt. Ltd. }\end{array}$ & 29.09 .2011 & {$[132]$} \\
\hline $\begin{array}{l}\text { Preservative system for ophthalmic } \\
\text { formulations }\end{array}$ & US5414011 & Syntex (U.S.A.) Inc. & 09.05 .1995 & {$[133]$} \\
\hline $\begin{array}{l}\text { Compounds and compositions for treating } \\
\text { neuronal death or neurological dysfunction. }\end{array}$ & US20090149542 & $\begin{array}{l}\text { Neurotech } \\
\text { Pharmaceuticals Co., }\end{array}$ & 11.06 .2009 & {$[134]$} \\
\hline $\begin{array}{l}\text { Micro-RNA-195 compositions and } \\
\text { therapeutic use in ocular diseases }\end{array}$ & US20190321389 & $\begin{array}{l}\text { China Medical } \\
\text { University }\end{array}$ & 24.10 .2019 & {$[135]$} \\
\hline $\begin{array}{l}\text { The novel method of treating macular } \\
\text { degeneration using botulinum toxin-based } \\
\text { pharmaceuticals }\end{array}$ & US20180344806 & Gary E. Borodic & 06.12 .2018 & {$[136]$} \\
\hline $\begin{array}{l}\text { Combination of cell necrosis inhibitor and } \\
\text { lithium for treating neuronal death or } \\
\text { neurological dysfunction }\end{array}$ & US20070049565 & $\begin{array}{l}\text { Neurotech } \\
\text { Pharmaceuticals Co., } \\
\text { Ltd. }\end{array}$ & 01.03 .2007 & {$[137]$} \\
\end{tabular}

\section{Conclusions}

Diabetic retinopathy is a worldwide rising chronic microvascular disorder commonly causes vision loss in affected individuals. The identified risk factors for DR include long-term $\mathrm{DM}$, and high arterial blood pressure. The four major biochemical pathways for DR have been identified: increased polyol pathway fluxes, advanced glycation end product growth, protein kinase $\mathrm{C}$ isoform activation, and increased hexosamine pathway flux. The surgical treatment strategies for DR include laser treatment, panretinal photocoagulation, focal laser photocoagulation and vitrectomy surgery. Furthermore, the systemic treatment approaches include management of glycemic, blood pressure, and hyperlipidemia. Nowadays, the remarkable alternatives for the treatment of DR are based on nano-based formulations like nanoparticles, polymeric nanomicelles, and nanocarrier composite. Based on investigations by several researchers summarized in this review, it has been conclusively established that DR can be treated better with nanotechnology-based approaches.

\section{Funding}

None.

\section{Acknowledgments}

The authors express gratitude to Chitkara College of Pharmacy, Chitkara University, Punjab, India, for motivational support for this review's compilation.

\section{Conflict of Interest}

The authors declare no conflict of interest. 


\section{References}

1. Lin, Y.K.; Gao, B.; Liu, L.; Ang, L.; Mizokami-Stout, K.; Pop-Busui, R.; Zhang, L. The Prevalence of diabetic microvascular complications in china and the USA. Curr. Diabetes Rep. 2021, 21, 1-1, https://doi.org/10.1007/s11892-021-01387-3.

2. Zhou, H.R.; Kuang, H.Y. Circular RNAs: Novel target of diabetic retinopathy. Rev. Endocr. Metab. Dis. 2021, 22, 205-216, https://doi.org/10.1007/s11154-021-09646-0.

3. Grzybowski, A.; Brona, P.; Lim, G.; Ruamviboonsuk, P.; Tan, G.S.; Abramoff, M.; Ting, D.S. Artificial intelligence for diabetic retinopathy screening: a review. Eye 2020, 34, 451-460, https://doi.org/10.1038/s41433-019-0566-0.

4. Smith-Morris, C.; Bresnick, G.H.; Cuadros, J.; Bouskill, K.E.; Pedersen, E.R. Diabetic retinopathy and the cascade into vision loss. Med. Anthropol. 2020, 39, 109-122, https://doi.org/10.1080/01459740.2018.1425839.

5. Wong, T.Y.; Sabanayagam, C. Strategies to tackle the global burden of diabetic retinopathy: from epidemiology to artificial intelligence. Ophthalmol. 2020, 243, 9-20, https://doi.org/10.1159/000502387.

6. Holman, R.R.; Paul, S.K.; Bethel, M.A.; Matthews, D.R.; Neil, H.A. 10-year follow-up of intensive glucose control in type 2 diabetes. N. Engl. J. Med. 2008, 359, 1577-1589, https://doi.org/10.1056/NEJMoa0806470.

7. Klein, R.; Knudtson, M.D.; Lee, K.E.; Gangnon, R.; Klein, B.E. The Wisconsin Epidemiologic Study of Diabetic Retinopathy XXIII: the twenty-five-year incidence of macular edema in persons with type 1 diabetes. Ophthalmology 2009, 116, 497-503, https://doi.org/10.1016/j.ophtha.2008.10.016

8. Raman, R.; Rani, P.K.; Kulothungan, V.; Rachepalle, S.R.; Kumaramanickavel, G.; Sharma, T. Influence of serum lipids on clinically significant versus nonclinically significant macular edema: SN-DREAMS Report number 13. Ophthalmology 2010, 117, 766-772, https://doi.org/10.1016/j.ophtha.2009.09.005.

9. Polemiti, E.; Baudry, J.; Kuxhaus, O.; Jäger, S.; Bergmann, M.M.; Weikert, C.; Schulze, M.B. BMI and BMI change following incident type 2 diabetes and risk of microvascular and macrovascular complications: the EPIC-Potsdam study. Diabetologia 2021, 64, 814-825, https://doi.org/10.1007/s00125-020-05362-7.

10. Olsen, B.S.; Sjolie, A.K.; Hougaard, P.; Johannesen, J.; Marinelli, K.; Jacobsen, B.B.; Mortensen, H.B. The significance of the prepubertal diabetes duration for the development of retinopathy and nephropathy in patients with type 1 diabetes. J. Diabetes Complications 2004, 18, 160-164, https://doi.org/10.1016/S10568727(03)00073-4.

11. Rasmussen, K.L.; Laugesen, C.S.; Ringholm, L.; Vestgaard, M.; Damm, P.; Mathiesen, E.R. Progression of diabetic retinopathy during pregnancy in women with type 2 diabetes. Diabetologia 2010, 53, 1076-1083, https://doi.org/10.1007/s00125-010-1697-9.

12. Joussen, A.M.; Smyth, N.; Niessen, C. Pathophysiology of diabetic macular edema. Dev. Ophthalmol. 2007, 39, 1-12, https://doi.org/10.1159/000098495.

13. Bianchi, E.; Ripandelli, G.; Taurone, S.; Feher, J.; Plateroti, R.; Kovacs, I.; Magliulo, G.; Orlando, M.P.; Micera, A.; Battaglione, E.; Artico, M. Age and diabetes related changes of the retinal capillaries: An ultrastructural and immunohistochemical study. Int. J. Immunopath. Ph. 2016, 29, 40-53, https://doi.org/10.1177/0394632015615592.

14. Rhea, E.M.; Banks, W.A. Role of the blood-brain barrier in central nervous system insulin resistance. Front. Neurosci. 2019, 4, 521, https://doi.org/10.3389/fnins.2019.00521.

15. Lin, A.; Peiris, N.J.; Dhaliwal, H.; Hakim, M.; Li, W.; Ganesh, S.; Ramaswamy, Y.; Patel, S; Misra, A. Mural Cells: Potential Therapeutic Targets to Bridge Cardiovascular Disease and Neurodegeneration. Cells 2021, 10, 593, https://doi.org/10.3390/cells10030593.

16. Rodríguez, M.L.; Pérez, S.; Mena-Mollá, S.; Desco, M.C.; Ortega, Á.L. Oxidative stress and microvascular alterations in diabetic retinopathy: Future Therapies. Oxid. Med. Cell. Longev. 2019, 2019, 4940825, https://doi.org/10.1155/2019/4940825.

17. Kang, Q.; Yang, C. Oxidative stress and diabetic retinopathy: Molecular mechanisms, pathogenetic role and therapeutic implications. Redox Biol. 2020, 101799, https://doi.org/10.1016/j.redox.2020.101799.

18. Ahuja, S.; Saxena, S.; Akduman, L.; Meyer, C.H.; Kruzliak, P.; Khanna, V.K. Serum vascular endothelial growth factor is a biomolecular biomarker of severity of diabetic retinopathy. Int. J. Retin. Vitr. 2019, 5, 1-6, https://doi.org/10.1186/s40942-019-0179-6.

19. Raman, P.; Singal, A.K.; Behl, A. Effect of Insulin-Like Growth Factor-1 on Diabetic Retinopathy in Pubertal Age Patients With Type 1 Diabetes. Asia-Pac. J. Ophthalmol. (Philadelphia, Pa.). 2019, 8, 319-323, https://dx.doi.org/10.1097\%2FAPO.0000000000000250.

20. Hussain, R.M.; Neiweem, A.E.; Kansara, V.; Harris, A.; Ciulla, T.A. Tie-2/Angiopoietin pathway modulation as a therapeutic strategy for retinal disease. Expert Opin. Investing. Drugs. 2019, 28, 861-869, https://doi.org/10.1080/13543784.2019.1667333. 
21. Semeraro, F.; Morescalchi, F.; Cancarini, A.; Russo, A.; Rezzola, S.; Costagliola, C. Diabetic retinopathy, a vascular and inflammatory disease: therapeutic implications. Diabetes Metab. 2019, 45, 517-527, https://doi.org/10.1016/j.diabet.2019.04.002.

22. Rezzola, S.; Guerra, J.; Krishna Chandran, A.M.; Loda, A.; Cancarini, A.; Sacristani, P.; Semeraro, F.; Presta, M. VEGF-Independent Activation of Müller Cells by the Vitreous from Proliferative Diabetic Retinopathy Patients. Int. J. Mol. Sci. 2021, 22, 2179, https://doi.org/10.3390/ijms22042179.

23. Yun, J.H. Hepatocyte growth factor prevents pericyte loss in diabetic retinopathy. Microvasc. Res. 2021, 133, 104103, https://doi.org/10.1016/j.mvr.2020.104103.

24. Khaloo, P.; Qahremani, R.; Rabizadeh, S.; Omidi, M.; Rajab, A.; Heidari, F.; Farahmand, G.; Bitaraf, M.; Mirmiranpour, H.; Esteghamati, A.; Nakhjavani, M. Nitric oxide and TNF- $\alpha$ are correlates of diabetic retinopathy independent of hs-CRP and HbAlc. Endocrine 2020, 69, 536-541, https://doi.org/10.1007/s12020-020-02353-X.

25. Yao, Y.; Li, R.; Du, J.; Long, L.; Li, X.; Luo, N. Interleukin-6 and diabetic retinopathy: a systematic review and meta-analysis. Curr. Eye Res. 2019, 44, 564-574, https://doi.org/10.1080/02713683.2019.1570274.

26. Stitt, A.W.; Bhaduri, T.; McMullen, C.T.; Gardiner, T.A.; Archer, D.B. Advanced glycation end products induce blood-retinal barrier dysfunction in normoglycemic rats. Mol. Cell Biol. Res. Commun. 2000, 3, 380388, https://doi.org/10.1006/mcbr.2000.0243.

27. Pang, L.; Lian, X.; Liu, H.; Zhang, Y.; Li, Q.; Cai, Y.; Ma, H.; Yu, X. Understanding diabetic neuropathy: focus on oxidative stress. Oxid. Med. Cell. Longev. 2020, 2020, https://doi.org/10.1155/2020/9524635.

28. Schlotterer, A.; Kolibabka, M.; Lin, J.; Acunman, K.; Dietrichá, N.; Sticht, C.; Fleming, T.; Nawroth, P.; Hammes, H.P. Methylglyoxal induces retinopathy-type lesions in the absence of hyperglycemia: studies in a rat model. Faseb J. 2019, 33, 4141-4153, https://doi.org/10.1096/fj.201801146RR.

29. Bolton, W. K.; Cattran, D. C.; Williams, M. E.; Adler, S. G.; Appel, G. B.; Cartwright, K.; Wuerth, J. P. Randomized trial of an inhibitor of formation of advanced glycation end products in diabetic nephropathy. Am. J. Nephrol. 2004, 24, 32-40, https://doi.org/10.1159/000075627.

30. Song, J.; Yang, X.; Yan, L.J. Role of pseudohypoxia in the pathogenesis of type 2 diabetes. Hypoxia 2019, 7, 33-40, https://doi.org/10.2147/HP.S202775.

31. Du, X. L.; Edelstein, D.; Rossetti, L.; Fantus, I. G.; Goldberg, H.; Ziyadeh, F.; Brownlee, M. Hyperglycemiainduced mitochondrial superoxide overproduction activates the hexosamine pathway and induces plasminogen activator inhibitor-1 expression by increasing Sp1 glycosylation. Proc. Natl. Acad. Sci. 2000, 97, 12222-12226, https://doi.org/10.1073/pnas.97.22.12222.

32. Soriano, F. G.; Virag, L.; Jagtap, P.; Szabo, E.; Mabley, J. G.; Liaudet, L.; Marton, A.; Hoyt, D.G.; Murthy, K.G.K.; Salzman, A.L.; Southan, G.J.; Szabo, C. Diabetic endothelial dysfunction: the role of poly (ADPribose) polymerase activation. Nat. Med. 2001, 7, 108-113, https://doi.org/10.1038/83241.

33. Wang, Q.J. PKD at the crossroads of DAG and PKC signaling. Trends Pharmacol. Sci. 2006, 27, 317-323, https://doi.org/10.1016/j.tips.2006.04.003.

34. Rosse, C.; Linch, M.; Kermorgant, S.; Cameron, A. J.; Boeckeler, K.; Parker, P. J. PKC and the control of localized signal dynamics. Nat. Rev. Mol. Cell Biol. 2010, 11, 103-112, https://doi.org/10.1038/nrm2847.

35. Ramana, K.V.; Friedrich, B.; Tammali, R.; West, M.B.; Bhatnagar, A.; Srivastava, S.K. Requirement of aldose reductase for the hyperglycemic activation of protein kinase $\mathrm{C}$ and formation of diacylglycerol in vascular smooth muscle cells. Diabetes 2005, 54, 818-829, https://doi.org/10.2337/diabetes.54.3.818.

36. Geraldes, P.; King, G.L. Activation of protein kinase $\mathrm{C}$ isoforms and its impact on diabetic complications. Circ. Res. 2010, 106, 1319-1331, https://doi.org/10.1161/CIRCRESAHA.110.217117.

37. Antonetti, D.A.; Silva, P.S.; Stitt, A.W. Current understanding of the molecular and cellular pathology of diabetic retinopathy. Nat. Rev. Endocrinol. 2021, 17, 195-206, https://doi.org/10.1038/s41574-020-00451-4.

38. Rudraraju, M.; Narayanan, S.P.; Somanath, P.R. Regulation of blood-retinal barrier cell-junctions in diabetic retinopathy. Pharmacol. Res. 2020, 161, 105115, https://doi.org/10.1016/j.phrs.2020.105115.

39. Coughlin, B.A.; Feenstra, D.J.; Mohr, S. Muller cells and diabetic retinopathy. Vision Res. 2017, 139, 93100. https://doi.org/10.1016/j.visres.2017.03.013.

40. Domènech, E.; Marfany, G. The relevance of oxidative stress in the pathogenesis and therapy of retinal dystrophies. Antioxidants 2020, 9, 347, https://doi.org/10.3390/antiox9040347.

41. Nguyen-Ba-Charvet, K.T.; Rebsam, A. Neurogenesis and specification of retinal ganglion cells. Int. J. Mol. Sci. 2020, 21, 451, https://doi.org/10.3390/ijms21020451.

42. Tran, N.M.; Shekhar, K.; Whitney, I.E.; Jacobi, A.; Benhar, I.; Hong, G.; Yan, W.; Adiconis, X.; Arnold, M.E.; Lee, J.M.; Levin, J.Z. Single-cell profiles of retinal ganglion cells differing in resilience to injury reveal neuroprotective genes. Neuron 2019, 104, 1039-1055, https://doi.org/10.1016/j.neuron.2019.11.006.

43. Potilinski, M.C.; Lorenc, V.; Perisset, S.; Gallo, J.E. Mechanisms behind retinal ganglion cell loss in diabetes and therapeutic approach. Int. J. Mol. Sci. 2020, 21, 2351, https://doi.org/10.3390/ijms21072351. 
44. Zhang, J.; Liu, R.; Kuang, H.Y.; Gao, X.Y.; Liu, H.L. Protective treatments and their target retinal ganglion cells in diabetic retinopathy. Brain Res. Bull. 2017, 132, 53-60, https://doi.org/10.1016/j.brainresbull.2017.05.007.

45. Baudry, M.; Bi, X. Calpain-1 and Calpain-2: the Yin and Yang of synaptic plasticity and neurodegeneration. Trends Neurosci. 2016, 39, 235-245, https://doi.org/10.1016/j.tins.2016.01.007.

46. Cui, Y.; Xu, N.; Xu, W.; Xu, G. Mesenchymal stem cells attenuate hydrogen peroxide-induced oxidative stress and enhance neuroprotective effects in retinal ganglion cells. In Vitro Cell. Dev. Biol. Anim. 2017, 53, 328-335, https://doi.org/10.1007/s11626-016-0115-0.

47. Hou, K.; Xu, D.; Li, F.; Chen, S.; Li, Y. The progress of neuronal autophagy in cerebral ischemia stroke: mechanisms, roles and research methods. J. Neurol. Sci. 2019,400, 72-82, https://doi.org/10.1016/j.jns.2019.03.015.

48. Dong, L.Y.; Jin, J.; Lu, G.; Kang, X.L. Astaxanthin attenuates the apoptosis of retinal ganglion cells in db/db mice by inhibition of oxidative stress. Mar. Drugs 2013, 11, 960-974, https://doi.org/10.3390/md11030960.

49. Cao, Y.; Wang, L.; Zhao, J.; Zhang, H.; Tian, Y.; Liang, H.; Ma, Q. Serum response factor protects retinal ganglion cells against high-glucose damage. J. Mol. Neurosci. 2016,59, 232-240, https://doi.org/10.1007/s12031-015-0708-1.

50. Chen, N.; Li, Y.; Huang, N.; Yao, J.; Luo, W.F.; Jiang, Q. The Nrf2 activator MIND4-17 protects retinal ganglion cells from high glucose-induced oxidative injury. J. Cell. Physiol. 2020, 235, 7204-7213, https://doi.org/10.1002/jcp.29619.

51. Wheeler, M.A.; Jaronen, M.; Covacu, R.; Zandee, S.E.; Scalisi, G.; Rothhammer, V.; Tjon, E.C.; Chao, C.C.; Kenison, J.E.; Blain, M.; Rao, V.T. Environmental control of astrocyte pathogenic activities in CNS inflammation. Cell 2019, 176, 581-596, https://doi.org/10.1016/j.cell.2018.12.012.

52. Yanuck, S.F. Microglial phagocytosis of neurons: diminishing neuronal loss in traumatic, infectious, inflammatory, and autoimmune CNS disorders. Front. Psychiatry 2019, 10, 712, https://doi.org/10.3389/fpsyt.2019.00712.

53. Chen, X.; Zhou, H.; Gong, Y.; Wei, S.; Zhang, M. Early spatiotemporal characterization of microglial activation in the retinas of rats with streptozotocin-induced diabetes. Graefes Arch. Clin. Exp. Ophthalmol. 2015, 253, 519-525, https://doi.org/10.1007/s00417-014-2727-y.

54. Karlstetter, M.; Scholz, R.; Rutar, M.; Wong, W.T.; Provis, J.M.; Langmann, T. Retinal microglia: just bystander or target for therapy? Prog. Retin. Eye Res. 2015, 45, 30-57, https://doi.org/10.1016/j.preteyeres.2014.11.004.

55. Hsia, N.Y.; Lin, C.J.; Lai, C.T.; Bair, H.; Chang, C.H.; Lin, J.M.; Tsai, Y.Y. Intravitreal Aflibercept as a rescue therapy for retinal neovascularization and macular edema due to Eales disease. Case Rep. Ophthalmol. Med. 2021, 2021, 888736, https://doi.org/10.1155/2021/8887362.

56. Jo, D.H.; Yun, J.H.; Cho, C.S.; Kim, J.H.; Cho, C.H. Interaction between microglia and retinal pigment epithelial cells determines the integrity of outer blood-retinal barrier in diabetic retinopathy. Glia 2019, 67, 321-331, https://doi.org/10.1002/glia.23542.

57. Turkowski, K.; Brandenburg, S.; Mueller, A.; Kremenetskaia, I.; Bungert, A.D.; Blank, A.; Felsenstein, M.; Vajkoczy, P. VEGF as a modulator of the innate immune response in glioblastoma. Glia 2018, 66, 161-174, https://doi.org/10.1002/glia.23234.

58. Yun, J.H.; Park, S.W.; Kim, K.J.; Bae, J.S.; Lee, E.H.; Paek, S.H.; Kim, S.U.; Ye, S.; Kim, J.H.; Cho, C.H. Endothelial STAT3 activation increases vascular leakage through downregulating tight junction proteins: implications for diabetic retinopathy. J. Cell. Physiol. 2017, 232, 1123-1134, https://doi.org/10.1002/jcp.25575.

59. Yu, P.K.; Balaratnasingam, C.; Morgan, W.H.; Cringle, S.J.; McAllister, I.L.; Yu, D.Y. The structural relationship between the microvasculature, neurons, and glia in the human retina. Invest. Ophthalmol. Vis. Sci. 2010, 51, 447-458, https://doi.org/10.1167/iovs.09-3978.

60. Reichenbach, A.; Bringmann, A. New functions of Muller cells. Glia 2013,61, 651-678, https://doi.org/10.1002/glia.22477.

61. Sorrentino, F.S.; Allkabes, M.; Salsini, G.; Bonifazzi, C.; Perri, P. The importance of glial cells in the homeostasis of the retinal microenvironment and their pivotal role in the course of diabetic retinopathy. Life Sci. 2016, 162, 54-59, https://doi.org/10.1016/j.lfs.2016.08.001.

62. MacDonald, R.B.; Randlett, O.; Oswald, J.; Yoshimatsu, T.; Franze, K.; Harris, W.A. Muller glia provide essential tensile strength to the developing retina. J. Cell Biol. 2015,210, 1075-1083, https://doi.org/10.1083/jcb.201503115.

63. Wohl, S.G.; Jorstad, N.L.; Levine, E.M.; Reh, T.A. Muller glial microRNAs are required for the maintenance of glial homeostasis and retinal architecture. Nat. Commun. 2017, 8, 1603, https://doi.org/10.1038/s41467017-01624-y. 
64. Rask-Madsen, C.; King, G.L. Kidney complications: factors that protect the diabetic vasculature. Nat. Med. 2010, 16, 40-41, https://doi.org/10.1038/nm0110-40.

65. Le, Y.Z. VEGF production and signaling in Muller glia are critical to modulating vascular function and neuronal integrity in diabetic retinopathy and hypoxic retinal vascular diseases. Vision Res. 2017, 139, 108114, https://doi.org/10.1016/j.visres.2017.05.005.

66. Roy, S.; Amin, S.; Roy, S. Retinal fibrosis in diabetic retinopathy. Exp. Eye Res. 2016, 142, 71-75, https://doi.org/10.1016/j.exer.2015.04.004.

67. Tang, H.; He, Y.; Li, L.; Mao, W.; Chen, X.; Ni, H.; Dong, Y.; Lyu, F. Exosomal MMP2 derived from mature osteoblasts promotes angiogenesis of endothelial cells via VEGF/Erk1/2 signaling pathway. Exp. Cell Res. 2019, 383, 111541, https://doi.org/10.1016/j.yexcr.2019.111541.

68. Rubsam, A.; Parikh, S.; Fort, P.E. Role of inflammation in diabetic retinopathy. Int. J. Mol. Sci. 2018, 19, 942, https://doi.org/10.3390/ijms19040942.

69. Attwell, D.; Mishra, A.; Hall, C.N.; O'Farrell, F.M.; Dalkara, T. What is a pericyte? J. Cereb. Blood Flow Metab. 2016, 36, 451-455, https://doi.org/10.1177\%2F0271678X15610340.

70. Sweeney, M.D.; Ayyadurai, S.; Zlokovic, B.V. Pericytes of the neurovascular unit: key functions and signaling pathways. Nat. Neurosci. 2016, 19, 771-783, https://doi.org/10.1038/nn.4288.

71. Kusuhara, S.; Fukushima, Y.; Ogura, S.; Inoue, N.; Uemura, A. Pathophysiology of diabetic retinopathy: the old and the new. Diabetes Metab. J. 2018, 42, 364-376, https://doi.org/10.4093/dmj.2018.0182.

72. Spencer, B.G.; Estevez, J.J.; Liu, E.; Craig, J.E.; Finnie, J.W. Pericytes, inflammation, and diabetic retinopathy. Inflammopharmacol. 2020, 28, 697-709, https://doi.org/10.1007/s10787-019-00647-9.

73. Valle, M.L.; Dworshak, J.; Sharma, A.; Ibrahim, A.S.; Shabrawey, M.Al.; Sharma. S. Inhibition of interleukin-6 trans-signaling prevents inflammation and endothelial barrier disruption in retinal endothelial cells. Exp. Eye Res. 2019, 178, 27-36, https://doi.org/10.1016/j.exer.2018.09.009.

74. Fu, H.; Liu, H. Deletion of toll-like receptor 4 ameliorates diabetic retinopathy in mice. Arch. Physiol. Biochem. 2020, 1-7, https://doi.org/10.1080/13813455.2020.1841795.

75. Rattner, A.; Williams, J.; Nathans, J. Roles of HIFs and VEGF in angiogenesis in the retina and brain. J. Clin. Invest. 2019, 130, 3807-3820, https://doi.org/10.1172/JCI126655.

76. Chhabra, M.; Sharma, S. Potential role of peroxisome proliferator activated receptor gamma analogues in regulation of endothelial progenitor cells in diabetes mellitus: an overview. Diabetes \& Metabolic Syndrome: Clin. Res. Rev. 2019, 13, 1123-1129, https://doi.org/10.1016/j.dsx.2019.01.036.

77. Lyons, C.J.; O'Brien, T. The Functionality of Endothelial-Colony-Forming Cells from Patients with Diabetes Mellitus. Cells 2020, 9, 1731, https://doi.org/10.3390/cells9071731.

78. Pyšná, A.; Bém, R.; Němcová, A.; Fejfarová, V.; Jirkovská, A.; Hazdrová, J.; Jude, E.B.; Dubský, M. Endothelial progenitor cells biology in diabetes mellitus and peripheral arterial disease and their therapeutic potential. Stem Cell Rev. Rep. 2019, 15, 157-165, https://doi.org/10.1007/s12015-018-9863-4.

79. Kusuyama, T.; Omura, T.; Nishiya, D.; Enomoto, S.; Matsumoto, R.; K. Takeuchi, K.; Yoshikawa, J.; Yoshiyama, M. Effects of treatment for diabetes mellitus on circulating vascular progenitor cells. J. Pharmacol. Sci. 2006, 102, 96-102, https://doi.org/10.1254/jphs.FP0060256.

80. Kalyva, A.; Marketou, M.E.; Parthenakis, F.I.; Pontikoglou, C.; Kontaraki, J.E.; Maragkoudakis, S.; Petousis, S.; Chlouverakis, G.; Papadaki, H.A.; Vardas, P.E. Endothelial progenitor cells as markers of severity in hypertrophic cardiomyopathy. Eur. J. Heart Fail. 2016, 18, 179-184, https://doi.org/10.1002/ejhf.436.

81. Singh, R.P.; Elman, M.J.; Singh, S.K.; Fung, A.E.; Stoilov, I. Advances in the treatment of diabetic retinopathy. J. Diabetes Complicat. 2019, 33, 107417, https://doi.org/10.1016/j.jdiacomp.2019.107417.

82. De Maria, M.; Panchal, B.; Coassin, M. Update on indications for diabetic vitrectomy and management of complications. Ann. Eye Sci. 2018, 3, 1-10, https://doi.org/10.21037/aes.2018.09.04.

83. Ren, X.; Bu, S.; Zhang, X.; Jiang, Y.; Tan, L.; Zhang, H.; Li, X. Safety and efficacy of intravitreal conbercept injection after vitrectomy for the treatment of proliferative diabetic retinopathy. Eye 2019, 33, 1177-1183, https://doi.org/10.1038/s41433-019-0396-0.

84. Newman, D.K. Surgical management of the late complications of proliferative diabetic retinopathy. Eye 2010, 24, 441-449, https://doi.org/10.1038/eye.2009.325.

85. Park, D.H.; Shin, J.P.; Kim, S.Y. Comparison of clinical outcomes between 23-gauge and 20- gauge vitrectomy in patients with proliferative diabetic retinopathy. Retina 2010, 30, 1662-1670, https://doi.org/10.1097/IAE.0b013e3181d95261.

86. Peto, T.; Chakravarthy, U. New findings from diabetic retinopathy clinical research retina network protocol $\mathrm{V}$ confirm a role for focal laser photocoagulation or observation for eyes with center-involved diabetic macular edema and good visual acuity: new is not always best. JAMA Ophthalmol. 2019, 137, 838-839, https://doi.org/10.1001/jamaophthalmol.2019.1876. 
87. Obeid, A.; Su, D.; Patel, S.N.; Uhr, J.H.; Borkar, D.; Gao, X.; Fineman, M.S.; Regillo, C.D.; Maguire, J.I.; Garg, S.J.; Hsu, J. Outcomes of eyes lost to follow-up with proliferative diabetic retinopathy that received panretinal photocoagulation versus intravitreal anti-vascular endothelial growth factor. Ophthalmology 2019, 126, 407-413, https://doi.org/10.1016/j.ophtha.2018.07.027.

88. Huang, C.X.; Lai, K.B.; Zhou, L.J.; Tian, Z.; Zhong, X.J.; Xu, F.B.; Gong, Y.J.; Lu, L.; Jin, C.J. Long-term effects of pattern scan laser pan-retinal photocoagulation on diabetic retinopathy in Chinese patients: a retrospective study. Int. J. Ophthalmol. 2020, 13, 239, https://dx.doi.org/10.18240\%2Fijo.2020.02.06.

89. Lu, A.J.; Freedman, I.G.; Shakir, O.; Adelman, R.A.; Del Priore, L.V. Panretinal photocoagulation along the long ciliary nerve in diabetic retinopathy. Ophthalmol. Retina. 2019, 3, 1105-1107, https://doi.org/10.1016/j.oret.2019.07.002.

90. Fong, D.S.; Girach, A.; Boney, A. Visual side effects of successful scatter laser photocoagulation surgery for proliferative diabetic retinopathy: a literature review. Retina 2007, 27, 816-824, https://doi.org/10.1097/IAE.0b013e318042d32c.

91. Zhang, J.; Liu, R.; Kuang, H.Y.; Gao, X.Y.; Liu, H.L. Protective treatments and their target retinal ganglion cells in diabetic retinopathy. Brain Res. Bull. 2017, 132, 53-60, https://doi.org/10.1016/j.brainresbull.2017.05.007.

92. The ACCORD Study Group; ACCORD Eye Study Group. Effects of medical therapies on retinopathy progression in type 2 diabetes. N Engl. J. Med. 2010, 363, 233-244, https://doi.org/10.1056/NEJMoa1001288.

93. Chew, E.Y.; Davis, M.D.; Danis, R.P.; Lovato, J.F.; Perdue, L.H.; Greven, C.; Genuth, S.; Goff, D.C.; Leiter, L.A.; Ismail-Beigi, F.; Ambrosius, W.T. The effects of medical management on the progression of diabetic retinopathy in persons with type 2 diabetes: the action to control cardiovascular risk in diabetes (ACCORD) eye study. Ophthalmol. 2014, 121, 2443-2451, https://doi.org/10.1016/j.ophtha.2014.07.019.

94. Ng, D.S.; Chiang, P.P.; Tan, G.; Cheung, C.G.; Cheng, C.Y.; Cheung, C.Y.; Wong, T.Y.; Lamoureux, E.L.; Ikram, M. Retinal ganglion cell neuronal damage in diabetes and diabetic retinopathy. Clin. Exp. Ophthalmol. 2016, 44, 243-250. https://doi.org/10.1111/ceo.12724.

95. Wilkinson-Berka, J.L. Angiotensin and diabetic retinopathy. Int. J. Biochem. Cell Biol. 2006, 38, 752-765, https://doi.org/10.1016/j.biocel.2005.08.002.

96. Elkjaer, A.S.; Lynge, S.K.; Grauslund, J. Evidence and indications for systemic treatment in diabetic retinopathy: a systematic review. Acta ophthalmologica 2020, 98, 329-336, https://doi.org/10.1111/aos.14377.

97. Bottino, L.G.; Fuchs, F.D. The role of angiotensin receptor blockers in CVD risk management. Expert Rev. Cardiovasc. Ther. 2020, 18, 181-185, https://doi.org/10.1080/14779072.2020.1750369.

98. Harindhanavudhi, T.; Mauer, M.; Klein, R.; Zinman, B.; Sinaiko, A.; Caramori, M. L.; Renin Angiotensin System Study (RASS) group. Benefits of Renin-Angiotensin blockade on retinopathy in type 1 diabetes vary with glycemic control. Diabetes Care 2011, 34, 1838-1842, https://doi.org/10.2337/dc11-0476.

99. Kang, E.Y.; Chen, T.H.; Garg, S.J.; Sun, C.C.; Kang, J.H.; Wu, W.C.; Hung, M.J.; Lai, C.C.; Cherng, W.J.; Hwang, Y.S. Association of statin therapy with prevention of vision-threatening diabetic retinopathy. JAMA Ophthalmol. 2019, 137, 363-371, https://doi.org/10.1001/jamaophthalmol.2018.6399.

100.Zhong, Y.; Yue, S.; Wu, J.; Guan, P.; Zhang, G.; Liu, L.; Chen, L. Association of the serum total cholesterol to triglyceride ratio with diabetic retinopathy in chinese patients with type 2 diabetes: a community-based study. Diabetes Ther. 2019, 10, 597-604, https://doi.org/10.1007/s13300-019-0579-5.

101.Keech, A.C.; Mitchell, P.; Summanen, P.A.; O'Day, J.; Davis, T.M.; Moffitt, M.S.; Merifield, A. Effect of fenofibrate on the need for laser treatment for diabetic retinopathy (FIELD study): A randomised controlled trial. Lancet 2007, 370, 1687-1697, https://doi.org/10.1016/S0140-6736(07)61607-9.

102.Thrimawithana, T.R.; Young, S.; Bunt, C.R.; Green, C.; Alany, R.G. Drug delivery to the posterior segment of the eye. Drug Discov. Today. 2011, 16(5-6), 270-277, https://doi.org/10.1016/j.drudis.2010.12.004.

103.Niri, A.D.; Faridi-Majidi, R.; Saber, R.; Khosravani, M.; Adabi, M. Electrospun carbon nanofiber-based electrochemical biosensor for the detection of hepatitis B virus. Biointerface Res. Appl. Chem. 2019, 9, 40224026, https://doi.org/10.33263/briac94.022026.

104.Maleki, M.J.; Pourhassan-Moghaddam, M.; Karimi, A.; Akbarzadeh, A.; Zarghami, N.; Mohammadi, S.A. Synthesis, characterisation, and application of chamomile gold nanoparticles in molecular diagnostics: a new component for PCR kits. Biointerface Res. Appl. Chem. 2019, 9, 4635-4641, https://doi.org/10.33263/briac96.635641.

105. Abou Gabal, R.; Shalaby, R.M.; Abdelghany, A.; Kamal, M. Antimicrobial effect, electronic and structural correlation of nano-filled Tin Bismuth metal alloys for biomedical applications. Biointerface Res. Appl. Chem. 2019, 9, 4340-4344. https://doi.org/10.33263/briac95.340344.

106.Zeini, M.; Divband, B.; Khezerloo, D.; Gharehaghaji, N. Biomedical applications of bismuth oxide based nanocomposite: computed tomography and anticancer drug loading. Biointerface Res. Appl. Chem. 2019, 9, 4101-4106, https://doi.org/10.33263/briac94.101106. 
107.Amanzadi, B.; Mirzaei, E.; Hassanzadeh, G.; Mandaviani, P.; Boroumand, S.; Abdollahi, M.; Abdolghaffari, A.H.; Majidi, R.F. Chitosan-based layered nanofibers loaded with herbal extract as wound-dressing materials on wound model studies. Biointerface Res. Appl. Chem. 2019, 9, 3979-3986, https://doi.org/10.33263/briac94.979986.

108.Ullah, F.; Javed, F.; Zakaria, M.R.; Jamila, N.; Khattak, R.; Khan, A.N.; Akil, H.M. Determining the molecular-weight and interfacial properties of chitosan built nanohydrogel for controlled drug delivery applications. Biointerface Res. Appl. Chem. 2019, 9, 4452-4457, https://doi.org/10.33263/briac96.452457.

109.Pawar, P.; Kashyap, H.; Malhotra, S.; Sindhu, R. Hp-CD-voriconazole in situ gelling system for ocular drug delivery: in vitro, stability, and antifungal activities assessment. BioMed Res. Int. 2013, 2013, 341218, https://doi.org/10.1155/2013/341218.

110.Grewal, A.S.; Lather, V.; Sharma, N.; Singh, S.; Narang, R.S.; Narang, J.K.; Pandita, D. Recent updates on nanomedicine based products: current scenario and future opportunities. Appl. Clin. Res. Clin. Trials Regul. Aff. 2018, 5, 132-144, https://doi.org/10.2174/2213476X05666180611115135.

111.Qiu, F.; Meng, T.; Chen, Q.; Zhou, K.; Shao, Y.; Matlock, G.; Deng, G. Fenofibrate-loaded biodegradable nanoparticles for the treatment of experimental diabetic retinopathy and neovascular age-related macular degeneration. Mol. Pharm. 2019, 16, 1958-1970, https://doi.org/10.1021/acs.molpharmaceut.8b01319.

112. Mahaling, B.; Srinivasarao, D. A.; Raghu, G.; Kasam, R. K.; Reddy, G. B.; Katti, D. S. A non-invasive nanoparticle mediated delivery of triamcinolone acetonide ameliorates diabetic retinopathy in rats. Nanoscale 2018, 10, 16485-16498, https://doi.org/10.1039/C8NR00058A.

113.Ibrahim, M. M.; Abd-Elgawad, A. E. H.; Soliman, O. A. E.; Jablonski, M. M. Stability and ocular pharmacokinetics of celecoxib-loaded nanoparticles topical ophthalmic formulations. J. Pharm. Sci. 2016, 105, 3691-3701, https://doi.org/10.1016/j.xphs.2016.09.019.

114.Ghezzi, M.; Pescina, S.; Padula, C.; Santi, P.; Del Favero, E.; Cantù, L.; Nicoli, S. Polymeric micelles in drug delivery: An insight of the techniques for their characterization and assessment in biorelevant conditions. $J$. Control. Release 2021, 332, 312-336, https://doi.org/10.1016/j.jconrel.2021.02.031.

115.Alvarez-Rivera, F.; Fernández-Villanueva, D.; Concheiro, A.; Alvarez-Lorenzo, C. $\alpha$-Lipoic acid in Soluplus ${ }^{\circledR}$ polymeric nanomicelles for ocular treatment of diabetes-associated corneal diseases. J. Pharm. Sci. 2016, 105, 2855-2863, https://doi.org/10.1016/j.xphs.2016.03.006.

116. Bamburowicz-Klimkowska, M.; Poplawska, M.; Grudzinski, I.P. Nanocomposites as biomolecules delivery agents in nanomedicine. J. Nanobiotech. 2019, 17, 48, https://doi.org/10.1186/s12951-019-0479-X.

117. Toragall, V.B.; Baskarn, V. Chitosan-sodium alginate-fatty acid nanocarrier composite: lutein bioavailability, absorption pharmacokinetics in diabetic rat and protection of retinal cells against $\mathrm{H} 2 \mathrm{O} 2$ induced oxidative stress in vitro. 2020, 254, 117409, https://doi.org/10.21203/rs.3.rs-51890/v1.

118.Laddha, U. D.; Kshirsagar, S. J. Formulation of PPAR-gamma agonist as surface modified PLGA nanoparticles for non-invasive treatment of diabetic retinopathy: in vitro and in vivo evidences. Heliyon 2020, 6, e04589, https://doi.org/10.1016/j.heliyon.2020.e04589.

119.Wang, J.; Tan, J.; Luo, J.; Huang, P.; Zhou, W.; Chen, L.; Deng, D. Y. Enhancement of scutellarin oral delivery efficacy by vitamin B12-modified amphiphilic chitosan derivatives to treat type II diabetes inducedretinopathy. J. nanobiotechnol. 2017, 15, 1-17, https://doi.org/10.1186/s12951-017-0251-z.

120.Lu, Y.; Zhou, N.; Huang, X.; Cheng, J. W.; Li, F. Q.; Wei, R. L.; Cai, J. P. Effect of intravitreal injection of bevacizumab-chitosan nanoparticles on retina of diabetic rats. Int. J. Ophthalmol. 2014, 7, 1, https://dx.doi.org/10.3980\%2Fj.issn.2222-3959.2014.01.01.

121.Geetha Krishnan, G. Herbal formulation for prevention and treatment of diabetic retinopthy. I.N. Patent 1223/DEL/2009. 2010.

122.Jacqueline, D.F.M.L.; Maria Helena, S.A.; Mariana Aparecida, R.B.; Aline, A.B. Pharmaceutical composition and formulation for non-invasive eye treatment, and uses thereof. W.O. Patent 2016205908. 2016.

123. Yunhee, K.U.; Yongju, Y.; Youngsoo, K.; Jonghwa, J.; Kyunggon, K.; Moosub, K.; Seungyeon, S. Marker for diagnosing diabetic retinopathy and use thereof. W.O. Patent 2014003343. 2014.

124. Wang, Y. Traditional chinese medicine formulation for treating diabetic retinopathy. C.N. Patent 106309841. 2017.

125.Sharma, D.S.; Singh S.; Kumar, S. A novel formulation of 5-fluorouracil for treating diabetic retinopathy. I.N. Patent 201911049029. 2019.

126.Rafael, S.C.; Cristina, H.P.; Jimena, F.C.; Marc, G.C.; Ribera, J.I.L.; Josep, F.S.; Berta, P.O. Topical ophthalmic peptide formulation. N.Z. Patent 600627. 2014.

127. Akita, M.; Mizuno, K.; Matsubara, A.; Nakano, K.; Kurono, M. Advancement inhibitor or therapeutic agent for diabetic retinopathy simplex. J.P. Patent 1995242547. 1995.

128. Kevin, G.P.; Robert, S.; John, M.J.; Alexander, D.S. Formulations comprising a compound that activates tie2 and their use in treating ocular diseases. G.B. Patent 2540638. 2017. 
129.Prausnitz, M.R.; Edelhauser, F. H.; Patel Rajnikant, S.K. Methods and devices for drug delivery to ocular tissue using microneedle. N.Z. Patent 623752. 2015.

130. Venkatraman, S.; Joseph, R.R.; Yin Boey, C.F. Subconjuctival depot forming formulations for ocular drug delivery. W.O. Patent 2017184081. 2017.

131.Hank, S.H.J.; Chung-Ling, L.; Tzu-Ming, W. Micro-RNA-195 compositions and therapeutic use in ocular diseases. W.O. Patent 2018111784. 2018.

132.Hood, M.; Kowert, K.; Goetzel, P.C.; Meyertons, E.B. Herbal formulation for prevention and treatment of diabetes and associated complications. U.S. Patent 20110236488. 2011.

133.Fu, C.C.R; Lidgate, D.M. Preservative system for ophthalmic formulations. U.S. Patent 5414011. 1995.

134.Gwag, B.J.; Lee, Y.A.; Shin, J.H.; Cho, S.I.; Noh, J.S.; Cho, J.Y.; Kim, K.W.; Lim, H.R.; Lee, J.K.; Byun, H.Y.; Ko, S.Y.; Son, S.J.; Park, S.M. Compounds and compositions for treating neuronal death or neurological dysfunction. U.S. Patent 20090149542. 2009.

135.Suh-Hang, H.J.; Chung-Ling, L.; Tzu-Ming, W. Micro-RNA-195 compositions and therapeutic use in ocular diseases. U.S. Patent 20190321389. 2019.

136. Gary, E.B. Novel method of treating macular degeneration using botulinum toxin-based pharmaceuticals. U.S. Patent 20180344806. 2018.

137.Gwag, B.J.; Lee, Y.A.; Shin, J.H.; Cho, S.I.; Noh, J.S.; Cho, J.Y.; Kim, K.W.; Lim, H.R.; Lee, J.K.; Byun, H.Y. Combination of cell necrosis inhibitor and lithium for treating neuronal death or neurological dysfunction. U.S. Patent 20070049565. 2007. 